\title{
Effect of Diet on Experimental Pancreatitis in Rat
}

\author{
Tetsuo Maki, Goro Kakizaki, Toshio Sato, Yoichi Saito, \\ Yasuo Suda, Toshiyuki Onuma and Noriyoshi Hayasaka
}

Depurtment of Surgery (Prof. T. Maki), Tohoku University School of Medicine, Sendai

\begin{abstract}
In order to study the effect of diet on the incidence of experimental pancreatitis. ligation of the common bile duct was carried out in 179 rats which had been fed on six different types of diet for 4 to 6 months. The highest mortality rate and most marked histologic changes of the pancreas were observed in the group of high protein diet. It was assumed that the reactive pattern of the pincreas might be influenced by dietary composition.
\end{abstract}

In a previous paper of ours, ${ }^{1}$ we stated that the chronic and postoperative pancreatitis in Japan differed markedly in incidence and clinical manifestations from those in Western countries, and supposed that the difference in the reaction of the pancreas to various kinds of stress might be due to racial difference and to the mode of living, especially to dietary habits. The present paper deals with the experimental pancreatitis of rats and its relationship to the diet composition.

\section{Materials and Method}

One hundred and seventy-nine Wistar rats weighing about $50 \mathrm{~g}$ were divided into six groups (cf. Table 1): 43 rats were placed on a standard diet (Group I), 52 on a high protein diet (Group II), 25 on a high fat diet (Group III), 21 on a high protein and high fat diet (Group IV), 13 on a high carbohydrate diet (Group V) and 25 on a low protein and high fat diet (Group VI). The period of experimental feeding was 4-6 months. At the end of this period the rats in each group weighed 150 to $200 \mathrm{~g}$.

Then, 5 rats from each group were selected as controls without further treatment. After $10 \mathrm{mg}$ of Nembutal were injected subcutaneously, the abdomen was opened and $5 \mathrm{ml}$ of blood were aspirated from the abdominal aorta for the determination of blood amylase level by Wohlgemuth's method. A specimen of the pancreas was taken and fixed with $10 \%$ formalin and stained with hematoxylin and eosin, Masson's and PAS methods.

The remaining 149 rats were used for experimental production of acute pancreatitis by ligating with a fine silk thread the distal part of the common bile duct close to the duodenum, as described by Block. ${ }^{2}$ On the 4 th or 5 th postopera-

Received for publication, March 2, 1967. 
TABLE 1. Composition of diets for rats (g/day)

\begin{tabular}{|c|c|c|c|c|c|c|}
\hline Composition: & $\begin{array}{c}1 \\
\text { Stand- } \\
\text { ard }\end{array}$ & $\begin{array}{c}\text { II } \\
\text { High } \\
\text { protein }\end{array}$ & $\begin{array}{c}\text { III } \\
\text { High } \\
\text { fat }\end{array}$ & $\begin{array}{c}\text { IV } \\
\text { High } \\
\text { protein } \\
\text { high fat }\end{array}$ & $\begin{array}{c}\text { V } \\
\text { High } \\
\text { carbohyduate }\end{array}$ & $\begin{array}{c}\text { VI } \\
\text { Low } \\
\text { protein } \\
\text { high fat }\end{array}$ \\
\hline Starch (g) & 14.00 & 12.00 & 9.89 & 8.37 & 16.40 & 11.63 \\
\hline Case:n (g) & 3.40 & 5.43 & 3.40 & 5.43 & 2.00 & 1.60 \\
\hline$*$ Oil $\quad(\mathrm{g})$ & 1.60 & 1.60 & 5.71 & 5.71 & 0.60 & 5.71 \\
\hline tVitam:n $(g)$ & 0.17 & 0.17 & 0.17 & 0.17 & 0.17 & 0.17 \\
\hline${ }_{+}^{+}$Mineral (g) & 0.80 & 0.80 & 0.80 & 0.80 & 0.80 & 0.80 \\
\hline $\begin{array}{l}5096 \text { choline chloride } \\
(\mathrm{ml})\end{array}$ & 0.06 & 0.06 & 0.06 & 0.06 & 0.06 & 0.06 \\
\hline Calories per day & 86.22 & 86.22 & 107.59 & 109.68 & 81.02 & 109.95 \\
\hline
\end{tabular}

*Oil: Soy bean oil $80 \%$, cod liver oil $20 \%$

tVitamin mixture: Thiamine- $\mathrm{HCl} 0.059 \%$, riboflavin $0.059 \%$, nicotinic acid $0.294^{\circ}$, calcium pantothenate $0.235 \%$, pyridoxine $\cdot \mathrm{HCl}$ $0.029 \%$, vitamin $\mathrm{K}$ (Menadione) $0.006 \%$, biotin $0.001 \%$, folic acid $0.002 \%$, vitamin $\mathrm{B}_{12} 0.0002 \%$, inositol $1.176 \%$, ascorbic acid $0.588 \%$, lactose $97.551 \%$.

Mineral mixture: $\mathrm{CaCO}_{3} 29.29 \%$, $\mathrm{CaHPO}_{4} \cdot 2 \mathrm{H}_{2} \mathrm{O} 0.43 \%, \mathrm{KH}_{2} \mathrm{PO}_{4} 34.31 \%$, $\mathrm{NaCl} 25.06 \%, \mathrm{MgSO}_{4} \cdot 7 \mathrm{H}_{2} \mathrm{O} 9.98 \%, \mathrm{Fe}\left(\mathrm{C}_{6} \mathrm{H}_{5} \mathrm{O}_{7}\right) \cdot 6 \mathrm{H}_{2} \mathrm{O}$ $0.623 \%$, $\quad \mathrm{CuSO}_{4} \cdot 5 \mathrm{H}_{2} \mathrm{O} 0.156 \%, \quad \mathrm{MnSO}_{4} \cdot \mathrm{H}_{2} \mathrm{O} \quad 0.121 \%$ $\mathrm{ZnCl}_{4} 0.02 \%$, KI $0.0005 \%,\left(\mathrm{NH}_{4}\right)_{6} \mathrm{Mo}_{7} \mathrm{O}_{24} \cdot 4 \mathrm{H}_{2} \mathrm{O} 0.0025 \%$

tive day, levels of serum amylase were determined and pancreatic biopsy was done with the same method as that mentioned above.

\section{Results}

1) The rats that died within three days following ligation of the common bile duct

The cause of deaths. Of the 119 rats subjected to common bile duct ligation, 60 rats $(50 \%)$ died on the second or third postoperative day. Postmortem examination revealed gross evidence of acute pancreatitis with a marked dilatation of the common duct and wide-spread fat necrosis, and with ascites.

Mortality rate in each group. Sixty rats died within three days following the ligation of the common bile duct (Fig. 1). Out of 38 rats of the Group I, 10 rats $(26 \%)$ died, 4 of which died on the second postoperative day. Of 47 rats of the Group II, 16 rats died on the second postoperative day, the total number of death being $31(66 \%)$. In the Group III consisting of $20 \mathrm{rats}, 9(45 \%)$ died postoperatively, in which 5 died on the second day. Of the 16 rats of the Group IV, $3(19 \%)$ died on the third postoperative day. Eight rats of the Group V survived entirely three days. While 7 rats, $35 \%$ of 20 rats in the Group VI, died, 3 of which died on the second postoperative day.

The results showed that the mortality rate following ligation of the common bile duct ranged from 20 to $66 \%$ in all groups except Group V of high carbohydrate diet. It seemed likely that severe acute pancreatitis did not occur in the group of high carbohydrate diet. 


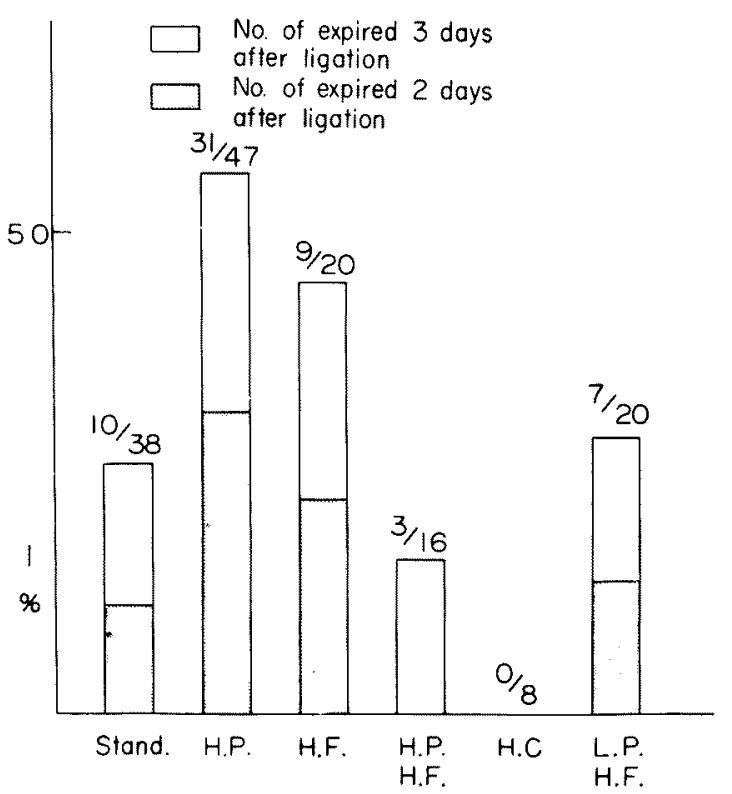

Fig. 1. Mortality rate after ligation of the common bile duct.

\section{2) The level of serum amylase}

Non-ligation group. The serum amylase did not exceed 32 units in 30 rats which had not been subjected to the ligation of the common bile duct.

Ligation group. The determination of serum amylase level was conducted on 89 rats surviving 3 or 4 days after ligation of the common bile duct (cf. Table 2). Out of the 89 rats, those with serum amylase levels lower than 32 units were 7 in number which consisted of 3 in Group V, 3 in Group VI and 1 in Group I.

Rats with serum amylase levels ranging from 64 to 256 units were 50 in number, which included $6(21.4 \%)$ of Group I, $14(87.5 \%)$ of Group II, $10(90.9 \%)$

TABLE 2. Level of serum amylase following common bile duct ligation

\begin{tabular}{|c|c|c|c|c|}
\hline $\begin{array}{l}\text { Amylase } \\
\text { level } \\
\text { Dietary } \\
\text { groups }\end{array}$ & $\begin{array}{c}\text { Less than } \\
32 \\
\text { units }\end{array}$ & $\begin{array}{c}64 \sim 256 \\
\text { units }\end{array}$ & $\begin{array}{l}\text { More than } \\
512 \\
\text { units }\end{array}$ & Total \\
\hline I & $1(3.6)$ & $6(21.4)$ & $21(75.0)$ & 28 \\
\hline II & 0 & $14(87.5)$ & $2(12.5)$ & 16 \\
\hline III & 0 & $10(90.9)$ & $1(9.1)$ & 11 \\
\hline IV & 0 & $10(76.9)$ & $3(23.1)$ & 13 \\
\hline V & $3(37.5)$ & $4(50,0)$ & $1(12.5)$ & 8 \\
\hline VI & $3(23.0)$ & $6(46.1)$ & $4(30.7)$ & 13 \\
\hline Total & 7 & 50 & 32 & 89 \\
\hline
\end{tabular}

Numbers in parentheses indicate percentage. 
of Groups III, $10(76.9 \%)$ of Group IV, $4(50 \%)$ of Group V and $6(46.1 \%)$ of Group VI.

Thirty-two rats showed serum amylase values of more than 512 units, and they included $21(75.0 \%)$ of Group I, $2(12.5 \%)$ of Group II, $1(9.1 \%)$ of Group III, 3 $(23.1 \%)$ of Group IV, $1(12.5 \%)$ of Group V and $4(30.7 \%)$ of Group VI.

All control rats without the ligation showed normal serum amylase levels. There was no significant difference in serum amylase levels among the six groups.

3) Gross findiugs at laparotomy

Non-ligation group. No gross abnormality other than a marked increase of adipose tissue was noted in Groups III and IV.

Ligation grony. All cases showed dilatation of the common bile duct, edema of the pancreas and ascites, but neither hemorrhagic nor neerotic pancreatitis was found. Fat necrosis was observed in more than one-half of the cases, without, however, no significant difference in its incidence among Groups I-VI.

4) Microscopic findings

Non-ligation group. There was no clear-cut difference in microscopic findings of pancreas among Groups I-VI.

Ligation group. The endocrine system of the pancreas: Hydropic change of the islet cell was noted in following frequencies: $2(7 \%)$ out of 28 of the Group I, 16 $(100 \%)$ in the Group II, $4(36 \%)$ out of 11 of the Group III, $5(38 \%)$ out of 13 of the Group IV, one (13\%) out of 8 of the Group V and one $(8 \%)$ out of 13 of the Group VI.

The exocrine system of the pancreas: Pleomorphism of the acinar cell was seen in $100 \%$ of Groups II, III and IV, but in $39 \%$ (11 out of 28 ) in Group I, $38 \%$ (3

TaBLe 3. Histological findings of experimentally produced acute pancreatitis

\begin{tabular}{|c|c|c|c|c|c|c|}
\hline $\begin{array}{l}\text { Histological } \\
\text { findings }\end{array}$ & $\begin{array}{l}\text { Stand- } \\
\text { ard }\end{array}$ & $\begin{array}{l}\text { High } \\
\text { protein }\end{array}$ & $\begin{array}{l}\text { High } \\
\text { fat }\end{array}$ & $\begin{array}{l}\text { High } \\
\text { protein } \\
\text { high } \\
\text { fat }\end{array}$ & $\begin{array}{c}\text { High } \\
\text { carbo- } \\
\text { hydrate }\end{array}$ & $\begin{array}{l}\text { Low } \\
\text { protein } \\
\text { high fat }\end{array}$ \\
\hline $\begin{array}{l}\text { Hydropic changes of } \\
\text { islet cells }\end{array}$ & - & $H$ & $H$ & + & & \\
\hline $\begin{array}{l}\text { Pleomorphism of acinar } \\
\text { cells }\end{array}$ & + & \# & $\#$ & t & + & $H$ \\
\hline Desquamation & - & H & + & H & + & + \\
\hline Intra-acinar exudation & + & H & $H$ & H & + & + \\
\hline $\begin{array}{l}\text { Vacuolization in acinar } \\
\text { cell }\end{array}$ & + & H & \# & $H$ & + & H \\
\hline Acinar ectasia & 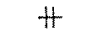 & $H$ & $H$ & $\#$ & + & $H$ \\
\hline $\begin{array}{l}\text { Exudation in interstitial } \\
\text { tissue }\end{array}$ & + & $H$ & H & $H$ & + & + \\
\hline $\begin{array}{l}\text { Exudation in } \\
\text { peripancreatic tissue }\end{array}$ & + & H & + & + & + & + \\
\hline
\end{tabular}


out of 8$)$ in V, and $77 \%(10$ out of 13$)$ in VI. Furthermore, necrobiosis of glandular components with desquamation of acinar cells was seen in $88 \%, 55 \%$ and $85 \%$ of the rats in Groups II, III and IV, respectively, but none in Groups I and V and only $8 \%$ in Group VI. Intra-acinar exudation or vacuolization in the acinar cell was noted in rats of all groups but more marked in Groups II, III and IV than in Groups I and V.

The ducts and interstitial tissues: Acinar ectasis or dilatation of the pancreatic ducts and exudation or inflammatory cell infiltration into the interstitial tissues were observed in all groups, but more marked in Groups II. III and IV.

The results are summarized in Table 3: two pluses denote a positivity rate of more than $50 \%$ of the cases, one plus $10 \%$ to $50 \%$ and minus less than $10 \%$. In short, the degree of reaction of the pancreas was slight in the Group V (Fig. 2), but severe with necrosis of acinar tissues in Gromps II, III and IV (Figs. 3 and 4).

\section{Discussion}

As mentioned above, Wistar rats weighing about $50 \mathrm{~g}$ were divided into six groups of different diets and were kept for 4 to 6 months: standard, high protein, high fat, high protein and high fat, high carbohydrate, and low protein and high fat diets. Five rats from each group were chosen at random as the control. As a stress to cause pancreatitis, the common bile duct just proximal to its entrance into the duodenum was ligated by Block's method. ${ }^{2}$ Block stated that Wistar rats were most suitable for this experiment because of the following reasons: 1) it is easy to make a common channel because many pancreatic ducts drain into the common bile duct, 2) the pathological change of the pancreas after ligation of the pancreatic ducts is more marked in rats than in other animals, and 3) it is economical to use small animals.

Following ligation of the common bile duct of 119 rats, 60 rats $(50 \%)$ died of acute pancreatitis. But there was no death in the group of high carbohydrate diet. Severe pancreatitis enough to lead to death did not occur in that group. Histologic study of the rats sacrificed on the th or 5th day following ligation of the common bile duct revealed that the degree of pancreatitis was more marked in groups of high protein, high fat, and high protein and high fat diet than in the high carbohydrate group, and that necrosis of the pancreas was found in as high as $88 \%$ of the rats in the high protein. $85 \%$ in the high protein and high fat, and $55 \%$ in the high fat group. No pancreatic necrosis was found in the groups of high carbohydrate and standard diet.

In the present study, levels of serum amylase did not exhibit a direct correlation either with the severity of pancreatitis or with diet itself, this being in agreement with the results of Bernard. ${ }^{3}$ It seems likely that the pancreas of the rats that had been kept on the high protein, high fat, or high protein and high fat diet is influenced easily by such stresses as ligation of the common bile duct, and that the pancreas of the rats on high carbohydrate diet is more resistant to various stresses. 
Namely, if we compare the pancreas of the former rats with that of Westerners and the pancreas of the latter with that of the Japanese, we may assume that the difference in the clinical pictures of pancreatitis which has been discussed in the previous paper can be reproduced by different diets. Furthermore, the fact that the incidence of chronic pancreatitis is increasing after the year of 1945 and that the severe case of acute pancreatitis is more frequently seen in the last decade in Japan could be explained by the change in dietary habit of the Japanese during this period.

As reported by many researchers, ${ }^{2}{ }^{4},{ }^{5}$ simple ligation of the common bile duct of rats causes edema and fat necrosis but no necrosis of pancreatic parenchyma. According to Popper et $a l .,{ }^{6,7}$ and Lium et al., ${ }^{8}$ combination of ligation of the pancreatic ducts and administration of drugs which stimulate the exocrine function of the pancreas is not enough, but further impairment of the blood supply is necessary to produce pancreatic parenchymal necrosis. In the present study also, only edema of the pancreas was caused by ligation of the common duct in Group I of standard diet and Group V of high carbohydrate diet.

What is, then, the underlying mechanism of the different manifestations of pancreatitis among varions dietary groups? Increased intraductal pressure after ligation of the common duct may lead to formation of a new common channel, especially when the trypsin activity is enhanced and an ample amount of pancreatic juice is secreted on account of high protein and high fat diets.

According to Block, ${ }^{2}$ however, it was impossible to produce pancreatic parenchymal necrosis in spite of feeding with special diets and administrating of drugs that increase pancreatic exocrine secretion. In the authors' experiment, increased exocrine secretion of the pancreas is expected by feeding rats with high protein and high fat diets for a long period. Grossman and his associates ${ }^{9}$ studied histology and secretion of pancreatic enzymes such as trypsin, amylase and lipase after they kept white rats weighing from 100 to $150 \mathrm{~g}$ on a special diet for 21 days. They found the following results; a marked increase of amylase and a decrease of trypsin output on a high carbohydrate diet, an increase of trypsin, a moderate increase of lipase and a decrease of amylase output on a high protein diet and no increase of amylase and no change of lipase and trypsin on a high fat diet. Therefore, in the authors' experiment, where the rats were kept on special diets longer than theirs, it is considered that the rats which are fed on a high protein diet secrete highly concentrated trypsin in a larger amount and constantly and that the rats that had been on a high carbohydrate diet secrete less amount of trypsin.

\section{Summary}

One hundred and seventy-nine Wistar rats were divided into six groups of different diets and were kept on for four to six months and then subjected to ligation of the common bile duct just proximal to its opening to the duodenum. The results obtained were as follows:

1) Except one group of the high carbohydrate diet in which there was no death 
within three days following the ligation. $50 \%$ of the rats died on the second or third day, the highest mortality of $20-66 \%$ being found in the group of high protein diet.

2) No significant difference of serum amylase levels was found among the experimental groups.

3) The histologic study of the pancreas disclosed a severe parenchymal necrosis in the groups of high protein diet and high protein and high fat diet, whereas no such change was noted in the groups of high carbohydrate and standard diet.

4) It was assumed that the difference in clinical pictures of pancreatitis between the Japanese and Western peoples might be due to difference in dietary habit.

\section{Acknowledgment}

The authors are indebted to Professor X. Sasano, Department of Pathology for his valuable suggestions.

\section{References}

1) Maki, T., Kakizaki, G., Sato, T., Saito, Y., Onuma, T. \& Yamamoto, K. Difference in clinical manifestation of chronic pancreatitis between the Japanese and Western paoples. Tohok'u J. exp. Med., 1967, 92, 291299.

2) Block, M.A., Wakin, K.G., Baggenstoss, A.H. Experimental studies concerning factors in the pathogenesis of acute pancreatitis. Surg. Gynec. Obstet., 1954, 99, 83-90.

3) Bernard, H.R. Early Lapalotomy to Confirm Diagnosis of Acute Pancreatitis. Current Surgical Management, W. B. Saunders Co., Philadelphia and London, 1965.

4) Edlung, Y., Ekholm, R. \& Zelander, T. The morphological basis of acute pancreatic edema. A light and electron microscopic study on rats. Acta chir. scand., 1962, 123, $389-395$.

5) Nestel, P.J. Vascular factors in experimental acute pancreatitis. Med. J. Australia, $1957,44,86-88$.

6) Popper, H.L. \& Necheles, H. Edema of the pancreas. Surg. Gynec. Obstet., 1942, 74, 123-124.

7) Popper, H.L., Necheles. H. \& Russell, K.C. Transition of pancreatic edema into pancreatic necrosis. Surg. Gynec. Obstet., 1948, 87, 79-82.

8) Lium, R., Portsmouth, N.H. \& Maddock, S. Original communications. Etiology of acute pancreatitis. An experimental study. Surgery, 1948, 24, 593-604.

9) Grossman, M.I., Greengard, H. \& Ivy, A.C. The effect of dietary composition on pancreatic enzymes. Amer. J. Physiol., 1943, 138, 676-682. 


\section{Legends}

Fig. 2. Photomicrograph of the pancreas of a rat in Group $V$ with ligation of the common bile duct. Acinar ectasia and dilatation of the ducts as well as occasional vacuolization are present, but the acini are almost normal in structure and there is no necrobiosis or desquamation of acinar cells.

Fig. 3. Photomicrograph of the pancreas of a rat in Group III with ligation of the common bile dxct. Pleomorphism and occasional necrobiosis of acinar cells, acinar ectasia and dilatation of the ducts are evident. Vacuolized acinar cells are separated from the basement membrane.

Fig. 4. Photomicrograph of the pancreas of a rat in Group IV with ligation of the common bile duct. Infiltration of calls into the interstitial tissue is noted in addition to the same findings seen in Group III.

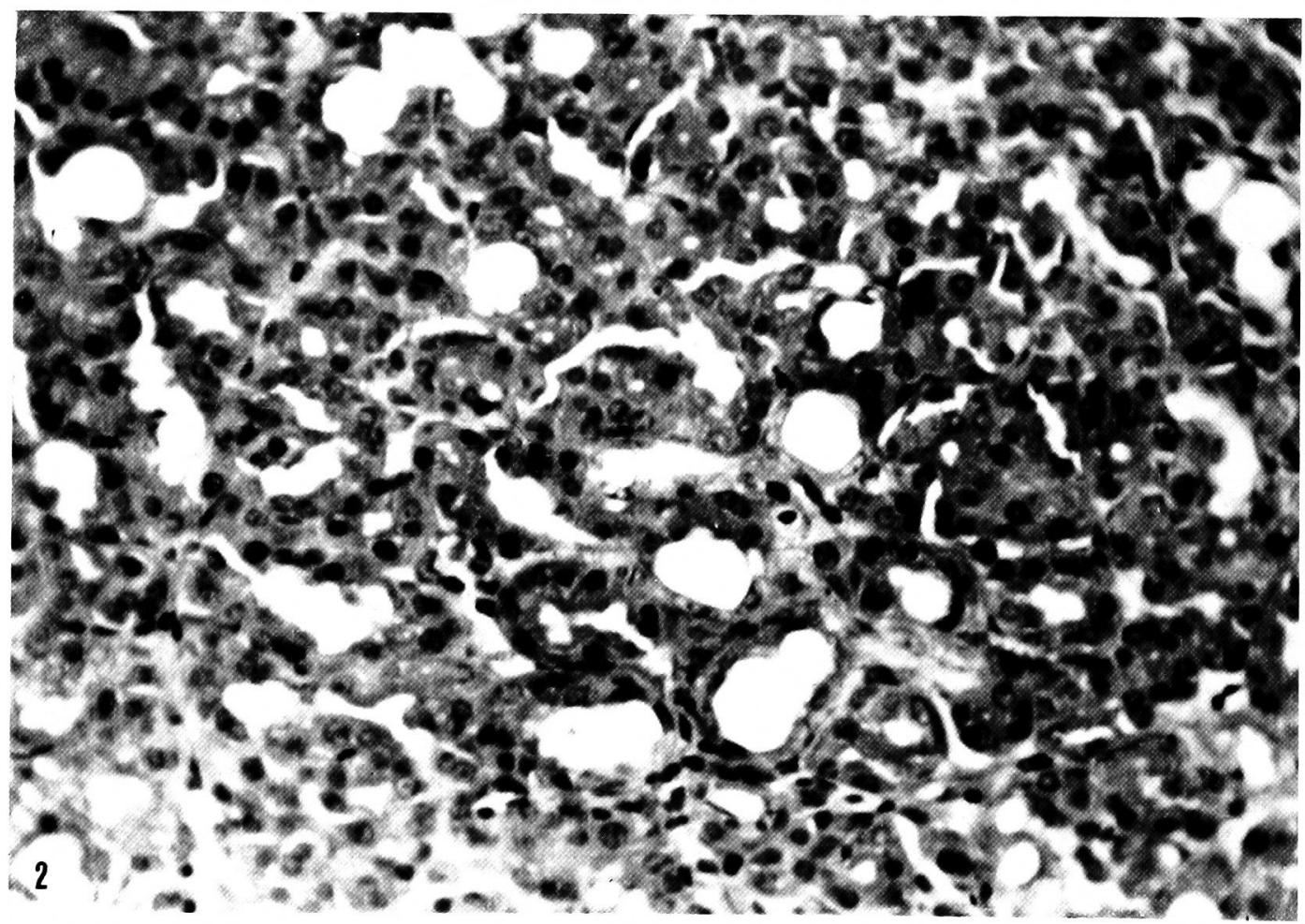




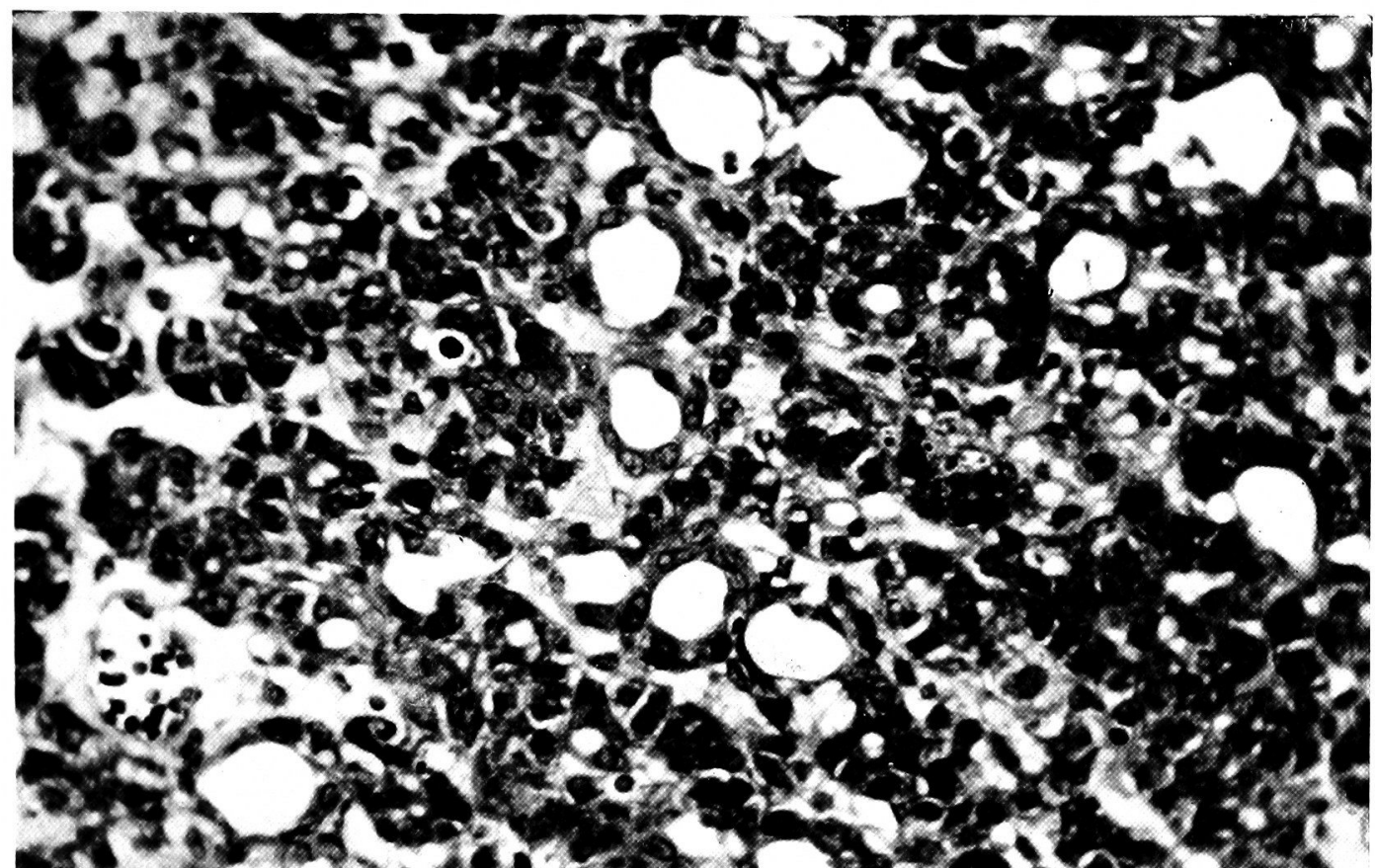

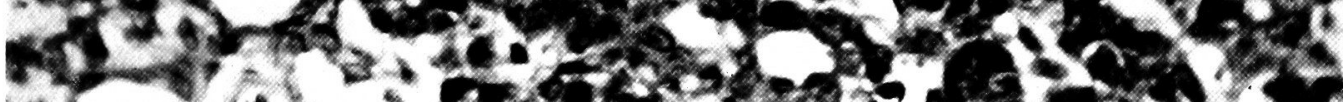

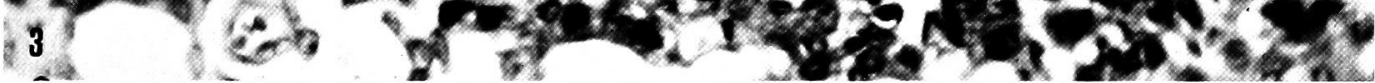

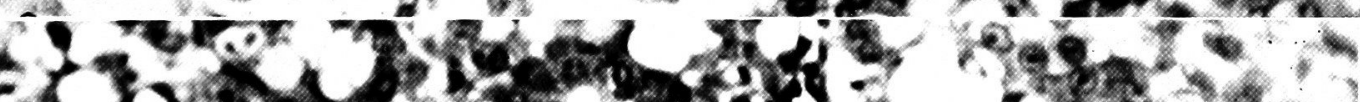

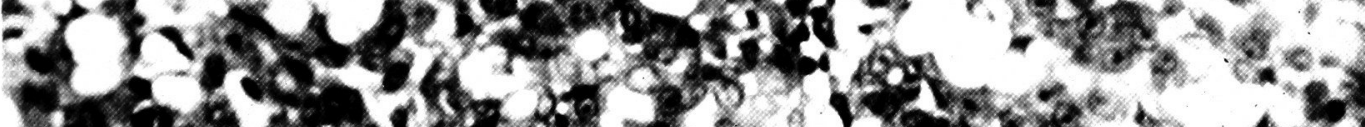

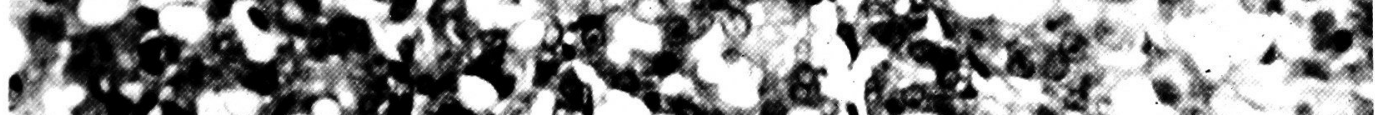

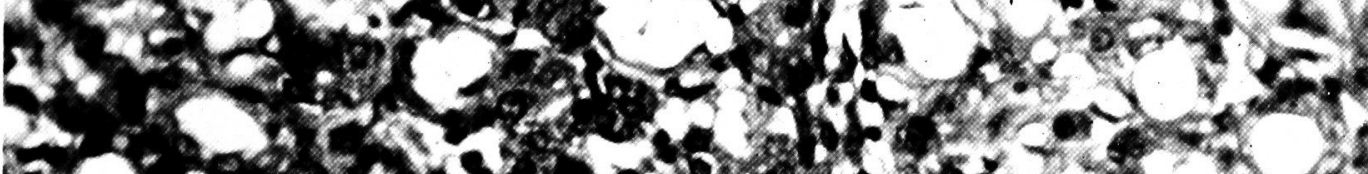

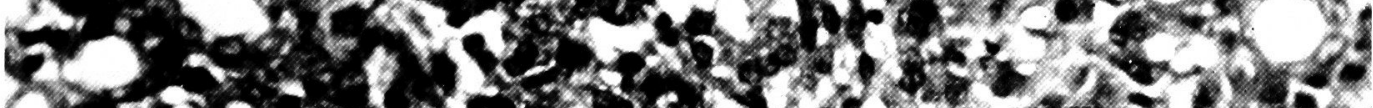

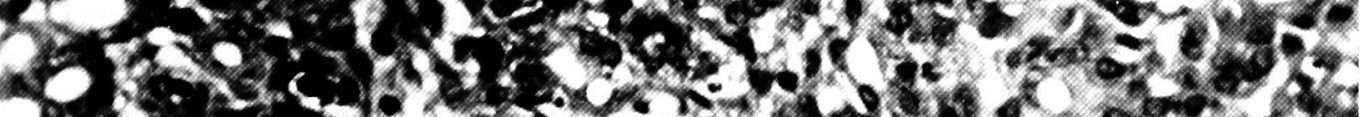

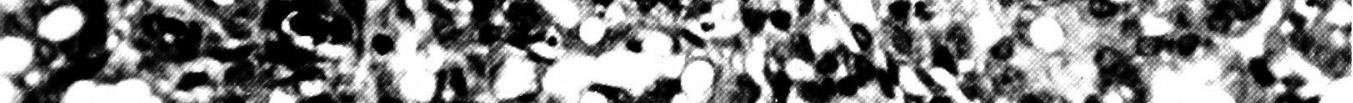

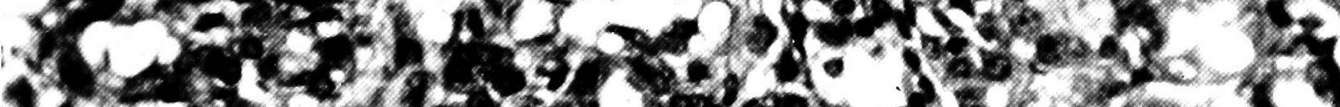

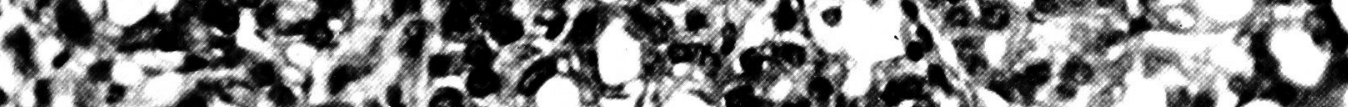

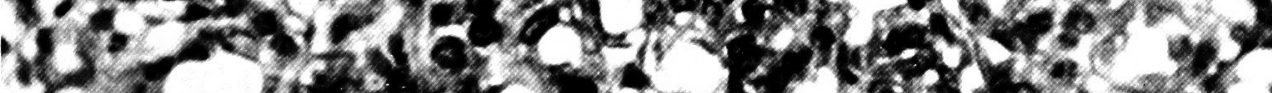

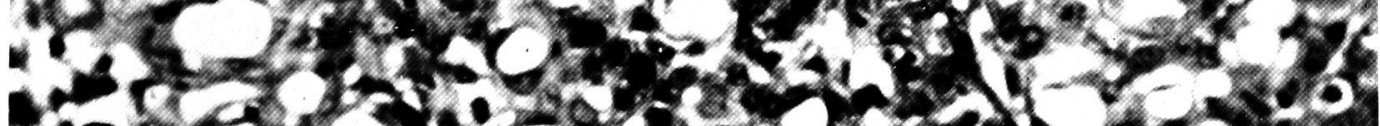

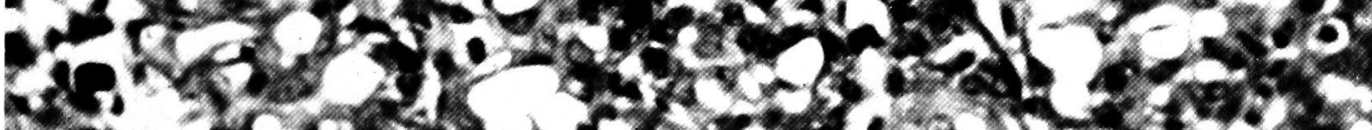

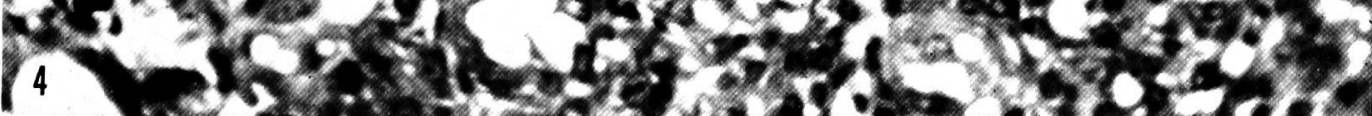

